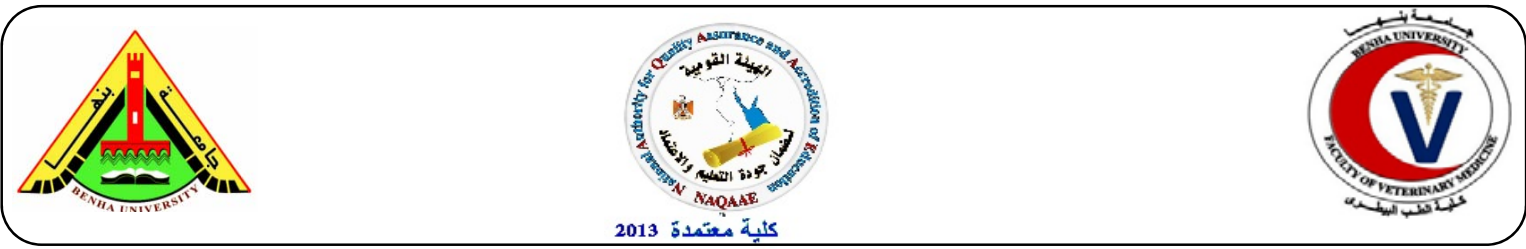

\title{
Monitoring the bacterial contamination during different stages of beef carcass preparation at Beni-Suef abattoir, Egypt
}

Fathy A. Khalafalla; Fatma H.M. Ali; Abdel-Rahim H.A. Hassan* and Kareem A. El-Feky

Food Hygiene Department, Faculty of Veterinary Medicine. Beni-Suef University, Beni-Suef, 62511, Egypt. *Corresponding author: Tel/Fax:+2 (082)2327982, Email: abdelrahim@vet.bsu.edu.eg

\section{A B S T R A C T}

In an attempt to monitor the levels of bacterial contamination during different stages of beef carcass preparation at Beni-Suef abattoir, Egypt, 20 beef carcasses were examined. Each carcass was represented by swabs from the abdomen, neck, shoulder, thigh and thorax, collected after dehiding, after evisceration and after complete preparation. Each swab was examined for the total mesophilic, psychrophilic and staphylococcal counts, MPN of coliforms, fecal coliforms and E. coli. The mesophilic counts in the examined swabs of abdomen, neck, shoulder, thigh and thorax after dehiding were $3 \times 10^{6}$, $3 \times 10^{6}, 5 \times 10^{6}, 7 \times 10^{5}, 3 \times 10^{6}$, while after evisceration, they changed to $2 \times 10^{7}, 5 \times 10^{6}, 4 \times 10^{6}, 5 \times 10^{5}, 2 \times 10^{6}$ $\mathrm{CFU} / \mathrm{cm}^{2}$, respectively. Moreover, they accounted for $5 \times 10^{5}, 5 \times 10^{6}, 7 \times 10^{6}, 2 \times 10^{5}, 5 \times 10^{6} \mathrm{CFU} / \mathrm{cm}^{2}$ after preparation, respectively. The staphylococcal counts in the examined swabs were $7 \times 10^{2}, 7 \times 10^{2}, 8 \times 10^{2}$, $7 \times 10^{2}, 8 \times 10^{2}$ after dehiding, $6 \times 10^{2}, 9 \times 10^{2}, 6 \times 10^{2}, 6 \times 10^{2}, 4 \times 10^{2} \mathrm{CFU} / \mathrm{cm}^{2}$ after evisceration, respectively. While, they were $4 \times 10^{2}, 9 \times 10^{2}, 10 \times 10^{2}, 6 \times 10^{2}, 3 \times 10^{2} \mathrm{CFU} / \mathrm{cm}^{2}$ after preparation, respectively. As regard to coliforms (MPN) in the examined swabs after dehiding, they were $2 \times 10$, $4 \times 10^{2}, 2 \times 10^{2}, 4 \times 10^{2}, 2 \times 10^{2}$, while $9,3 \times 10^{2}, 1 \times 10^{2}, 3 \times 10^{2}, 1 \times 10^{2}$ after evisceration, and $<3,3 \times 10^{2}$, $8 \times 10,2 \times 10,3 \times 10$ m.os. $/ \mathrm{cm}^{2}$ after preparation, respectively. The sources of contamination with the determined bacteria were discussed throughout the study.

Keywords: abattoir, bacterial contamination, APC, beef, coliforms MPN.

\section{INTRODUCTION}

$\mathrm{M}$ icrobial contamination of the carcass during slaughtering process result in spoilage of meat, reduce its shelf life and represents public health hazards (Nortje et al.,1990). Consequently, many food-borne outbreaks are related to consumption of meat containing pathogenic microorganisms. Efficient measure to reduce beef carcasses contamination begins with defining probable sources of contamination. Muscles of healthy cattle are usually sterile (Anderson et al., 1992); consequently, tissues become contaminated during the slaughtering practice. Sources of meat contamination during slaughtering could be classified into those associated with the animal, processing practices, abattoir facilities and workers. The hygienic and manufacturing practices inside the abattoir control the rate of bacterial contamination during slaughtering processes. Even in the best-managed slaughter facilities, contamination may still occur. Both nonpathogenic and pathogenic microorganisms have been isolated from beef carcasses inside abattoir (Dickson and Anderson, 1992). Animal sources of carcass contamination include the hide and gastrointestinal tract (Bell, 1997), 
additionally, the cutting of carcasses, involves the use of utensils, equipment and knives transfer more microorganism to beef tissues. Furthermore, the workers' hands, cloths and their instruments could spread contamination into the surface of beef carcasses (Gracey and Collins, 1992). In most developing countries, the absence or non-respect of exist hygienic practices in slaughtering, dressing and evisceration has been found to be one of the major causes of high surface contamination of beef carcasses by pathogenic and nonpathogenic microorganism (Eugène et al., 2013). Therefore, this study was carried out to monitor the surface contamination of beef carcasses during different stages of carcass preparation.

\section{MATERIAL AND METHODS}

\subsection{Collection of samples}

Twenty beef carcasses slaughtered at BeniSuef half-automatic abattoir (Beni-Suef, Egypt) were examined to monitor the degree of surface contamination during the stages of preparation. Each carcass was represented by swabs from the neck, thorax, shoulder, abdomen and thigh. The swabs were collected during three stages; after dehiding, evisceration and complete preparation using sterile cotton swabs. The collected swabs were identified and transferred with minimum delay in a sterile icebox to the laboratory for further preparation and examination.

\subsection{Bacteriological examination:}

\subsubsection{Samples preparation:}

Ten-fold serial dilutions were prepared from the cotton swabs using $0.1 \%$ sterile buffered peptone water.

\subsubsection{Bacteriological techniques:}

\subsubsection{Determination of mesophilic and psychrophilic counts:}

The pouring plate technique recommended by AOAC (1990) was used. In brief, one ml from each dilution was separately pipetted into a double set of sterile Petri dishes. 15 $\mathrm{ml}$ of melted standard plate count agar (Biolife; Italy) tempered at $45{ }^{\circ} \mathrm{C}$ were poured into each Petri dish, then thoroughly mixed and left to solidify. The inoculated plates were incubated in an inverted position at $36 \pm 1{ }^{\circ} \mathrm{C}$ for $48 \pm 2 \mathrm{~h}$ in case of mesophilic count, and at $7^{\circ} \mathrm{C}$ for 5 days in case of psychrophilic count. The plates that contain colonies between 30 and 300 were counted, and then the average count was multiplied by the dilution factor to get APC/ $\mathrm{cm}^{2}$ according to the following equation:

APC $/ \mathrm{cm}^{2}=$ Average number of colonies $\mathrm{x}$ dilution factor

\subsubsection{Determination of MPN of coliforms, fecal coliforms and $E$. coli:}

The three tubes MPN method recommended by AOAC (1990) was applied. Briefly, regarding the MPN of coliforms, Lauryl Sulphate Tryptose broth (LST) with inverted Durham's tube was used for presumptive coliforms count followed by a confirmatory step through using sterile test tubes containing Brilliant Green Bile Lactose broth (BGBL) with inverted Durham's tube for positive LST tubes. For fecal coliforms MPN, sterile test tubes containing $E$. coli broth (EC) with inverted Durham's tube were incubated at $44 \pm 0.5{ }^{\circ} \mathrm{C}$. While for E. coli MPN, a loopful from each positive EC broth tube was streaked onto the surface of Eosin Methylene Blue agar plate. The plates showing typical E. coli colonies (greenish metallic nucleated with dark purple center with or without sheen) were recorded. The MPN of each of coliforms, fecal coliforms and E. coli per $\mathrm{cm}^{2}$ of carcass surface was estimated according to the three tubes MPN table using the following equation:

$\mathrm{MPN} / \mathrm{cm}^{2}=$ Number from the table $\times$ middle dilution factor/100

\subsubsection{Staphylococcus aureus count:}

The technique recommended by AOAC (1990) was applied. For each dilution, duplicated plates of sterile dry Baird Parker's agar (BP; Oxoid; CM 275) were prepared. One hundred microliters from 
each dilution were spread by using sterile bent glass rod on the surface of plates. The plates were inverted and incubated at $35^{\circ} \mathrm{C}$ for 24 hours, suspected colonies (black, shiny and convex with narrow white margins and surrounded by clear zone extending into the opaque medium) were recorded. Plates were re-incubated at $35{ }^{\circ} \mathrm{C}$ for further 24 hours and the count is recorded. Staphylococcus aureus count per $\mathrm{cm}^{2}$ was calculated as follows:

Staphylococcus aureus $/ \mathrm{cm}^{2}=$ No. of colonies $\mathrm{x}$ dilution factor $\mathrm{x} 10$

\section{RESULTS}

Concerning the mesophilic counts, the obtained results in Table (1) indicated that the mean values of mesophilic count in the examined swab samples of abdomen, neck, shoulder, thigh and thorax after dehiding were $3 \times 10^{6} \pm 1 \times 10^{6}, 3 \times 10^{6} \pm 1 \times 10^{6}, 5 \times 10^{6}$ $\pm 2 \times 10^{6}, 7 \times 10^{5} \pm 2 \times 10^{5}, 3 \times 10^{6} \pm 1 \times 10^{6}$ $\mathrm{CFU} / \mathrm{cm}^{2}$, respectively. However, the results illustrated in Table (2) outlined them after evisceration, they accounted for $2 \times 10^{7}$ $\pm 1 \times 10^{7}, 5 \times 10^{6} \pm 2 \times 10^{6}, 4 \times 10^{6} \pm 2 \times 10^{6}$, $5 \times 10^{5} \pm 1 \times 10^{6}, 2 \times 10^{6} \pm 3 \times 10^{5} \mathrm{CFU} / \mathrm{cm}^{2}$, respectively. Moreover, after preparation they accounted for $5 \times 10^{5} \pm 2 \times 10^{5}, 5 \times 10^{6 \pm}$ $2 \times 10^{6}, 7 \times 10^{6} \pm 4 \times 10^{6}, 2 \times 10^{5} \pm 3 \times 10^{4}$, $5 \times 10^{6} \pm 2 \times 10^{6} \mathrm{CFU} / \mathrm{cm}^{2}$, respectively (Table, 3).

As regard to the psychrophilic counts, from the data outlined in Table (1), it could be clarified that in the examined carcass swabs from abdomen, neck, shoulder, thigh and thorax after dehiding they were $6 \times 10^{4} \pm$ $2 \times 10^{4}, 4 \times 10^{5} \pm 3 \times 10^{5}, 2 \times 10^{5} \pm 3 \times 10^{4}$, $2 \times 10^{4} \pm 8 \times 10^{3}, 2 \times 10^{5} \pm 3 \times 10^{4} \mathrm{CFU} / \mathrm{cm}^{2}$, respectively. While after evisceration they were $4 \times 10^{4} \pm 1 \times 10^{4}, 1 \times 10^{5} \pm 6 \times 10^{4}, 2 \times 10^{5} \pm$ $3 \times 10^{4}, \quad 6 \times 10^{4} \pm 2 \times 10^{4}, 5 \times 10^{5} \pm 3 \times 10^{5}$ $\mathrm{CFU} / \mathrm{cm}^{2}$, respectively (Table 2). After preparation they accounted for $7 \times 10^{4} \pm$ $3 \times 10^{4}, 9 \times 10^{4} \pm 3 \times 10^{4}, 2 \times 10^{5} \pm 3 \times 10^{4}$, $7 \times 10^{4} \pm 3 \times 10^{4}, 2 \times 10^{5} \pm 1 \times 10^{5} \mathrm{CFU} / \mathrm{cm}^{2}$, respectively (Table 3 ).

Regarding the staphylococcal counts, the illustrated results in Table (1) showed that in the examined carcass swabs from abdomen, neck, shoulder, thigh and thorax after dehiding they were $7 \times 10^{2} \pm 1 \times 10^{2}$, $7 \times 10^{2} \pm 1 \times 10^{2}, 8 \times 10^{2} \pm 2 \times 10^{2}, 7 \times 10^{2} \pm$ $1 \times 10^{2}, \quad 8 \times 10^{2} \pm 2 \times 10^{2} \quad \mathrm{CFU} / \mathrm{cm}^{2}$, respectively. Then after evisceration they accounted for $6 \times 10^{2} \pm 1 \times 10^{2}, 9 \times 10^{2} \pm$ $1 \times 10^{2}, 6 \times 10^{2} \pm 1 \times 10^{2}, 6 \times 10^{2} \pm 1 \times 10^{2}$, $4 \times 10^{2} \pm 1 \times 10^{2} \mathrm{CFU} / \mathrm{cm}^{2}$, respectively (Table 2). While after preparation were $4 \times 10^{2} \pm 1 \times 10^{2}, 9 \times 10^{2} \pm 1 \times 10^{2}, 10 \times 10^{2} \pm$ $5 \times 10^{2}, \quad 6 \times 10^{2} \pm 1 \times 10^{2}, 3 \times 10^{2} \pm 1 \times 10^{2}$ $\mathrm{CFU} / \mathrm{cm}^{2}$, respectively (Table 3). As concern to the coliforms (MPN), the aforementioned results in Table (1) clarified that in the examined carcass swabs from abdomen, neck, shoulder, thigh and thorax after dehiding they were $2 \times 10 \pm 1 \times 10$, $4 \times 10^{2} \pm 1 \times 10^{2}, 2 \times 10^{2} \pm 1 \times 10^{2}, 4 \times 10^{2} \pm$ $1 \times 10^{2}, \quad 2 \times 10^{2} \pm 1 \times 10^{2} \quad$ m.os. $/ \mathrm{cm}^{2}$, respectively. While those after evisceration were $9 \pm 6,3 \times 10^{2} \pm 1 \times 10^{2}, 1 \times 10^{2} \pm 7 \times 10$, $3 \times 10^{2} \pm 1 \times 10^{2}, 1 \times 10^{2} \pm 1 \times 10^{2}$ m.os. $/ \mathrm{cm}^{2}$, respectively (Table 2 ), and after preparation were $<3 \pm 0,3 \times 10^{2} \pm 1 \times 10^{2}, 8 \times 10 \pm 7 \times 10$, $2 \times 10 \pm 1 \times 10,3 \times 10 \pm 1 \times 10$ m.os. $/ \mathrm{cm}^{2}$, respectively (Table 3 ).

The results of fecal coliforms (MPN) were illustrated in Table (1), it was found that in the examined carcass swabs from abdomen, neck, shoulder, thigh and thorax after dehiding they were $9 \pm 6,9 \times 10 \pm 2 \times 10$, $3 \times 10 \pm 1 \times 10,9 \times 10 \pm 3 \times 10,3 \times 10 \pm 1 \times 10$ m.os. $/ \mathrm{cm}^{2}$, respectively. Whereas, the data in Table (2) outlined the fecal coliforms (MPN) in these samples after evisceration, which accounted for $<3 \pm 1,5 \times 10 \pm 2 \times 10$, $4 \pm 3,3 \times 10 \pm 1 \times 10,7 \pm 5$ m.os. $/ \mathrm{cm}^{2}$, respectively. While after preparation they were $<3 \pm 0,5 \times 10 \pm 2 \times 10,<3 \pm 2,7 \pm 5,<3$ \pm 0 m.os. $/ \mathrm{cm}^{2}$, respectively (Table 3 ). Furthermore, it could be clarified from Table (1) that the E. coli (MPN) in the examined carcass swabs from abdomen, neck, shoulder, thigh and thorax after dehiding were $4 \pm 3,4 \times 10 \pm 2 \times 10,1 \times 10 \pm$ $6,7 \times 10 \pm 3 \times 10,1 \times 10 \pm 6$ m.os. $/ \mathrm{cm}^{2}$, respectively. While after evisceration they were $<3 \pm 0,3 \times 10 \pm 1 \times 10,4 \pm 3,2 \times 10 \pm$ 
Table (1) Statistical analytical results of bacteriological examination of examined beef carcasses after dehiding, the data is represented by mean \pm Standard Error (CFU or m.os $\left./ \mathrm{cm}^{2}\right)(\mathrm{n}=20)$.

\begin{tabular}{lccccc}
\hline \multicolumn{1}{c}{ Parameters } & Neck & Thorax & Shoulder & Abdomen & Thigh \\
\hline Mesophilic count & $3 \times 10^{6} \pm 1 \times 10^{6}$ & $3 \times 10^{6} \pm 2 \times 10^{6}$ & $5 \times 10^{6} \pm 2 \times 10^{6}$ & $3 \times 10^{6} \pm 1 \times 10^{6}$ & $7 \times 10^{5} \pm 2 \times 10^{5}$ \\
Psychrophilic count & $4 \times 10^{5} \pm 3 \times 10^{5}$ & $2 \times 10^{5} \pm 3 \times 10^{4}$ & $2 \times 10^{5} \pm 3 \times 10^{4}$ & $6 \times 10^{4} \pm 2 \times 10^{4}$ & $2 \times 10^{4} \pm 8 \times 10^{3}$ \\
Staphylococcal count & $7 \times 10^{2} \pm 1 \times 10^{2}$ & $8 \times 10^{2} \pm 2 \times 10^{2}$ & $8 \times 10^{2} \pm 2 \times 10^{2}$ & $7 \times 10^{2} \pm 1 \times 10^{2}$ & $7 \times 10^{2} \pm 1 \times 10^{2}$ \\
Coliforms (MPN) & $4 \times 10^{2} \pm 1 \times 10^{2}$ & $7 \times 10 \pm 2 \times 10$ & $2 \times 10^{2} \pm 1 \times 10^{2}$ & $2 \times 10 \pm 1 \times 10$ & $4 \times 10^{2} \pm 1 \times 10^{2}$ \\
fecal coliforms & $9 \times 10 \pm 2 \times 10$ & $3 \times 10 \pm 9$ & $3 \times 10 \pm 1 \times 10$ & $9 \pm 6$ & $9 \times 10 \pm 3 \times 10$ \\
(MPN) & & & & & \\
E. coli (MPN) & $4 \times 10 \pm 2 \times 10$ & $1 \times 10 \pm 5$ & $1 \times 10 \pm 6$ & $4 \pm 3$ & $7 \times 10 \pm 3 \times 10$ \\
\hline
\end{tabular}

Table (2) Statistical analytical results of bacteriological examination of examined beef carcasses after evisceration, the data is represented by mean \pm Standard Error (CFU or m.os $\left./ \mathrm{cm}^{2}\right)(\mathrm{n}=20)$

\begin{tabular}{lccccc}
\hline \multicolumn{1}{c}{ Parameters } & Neck & Thorax & Shoulder & Abdomen & Thigh \\
\hline Mesophilic count & $5 \times 10^{6} \pm 2 \times 10^{6}$ & $2 \times 10^{6} \pm 3 \times 10^{5}$ & $4 \times 10^{6} \pm 2 \times 10^{6}$ & $2 \times 10^{7} \pm 1 \times 10^{7}$ & $5 \times 10^{5} \pm 1 \times 10^{6}$ \\
Psychrophilic count & $1 \times 10^{5} \pm 6 \times 10^{4}$ & $5 \times 10^{5} \pm 3 \times 10^{5}$ & $2 \times 10^{5} \pm 3 \times 10^{4}$ & $4 \times 10^{4} \pm 1 \times 10^{4}$ & $6 \times 10^{4} \pm 2 \times 10^{4}$ \\
Staphylococcal count & $9 \times 10^{2} \pm 1 \times 10^{2}$ & $4 \times 10^{2} \pm 1 \times 10^{2}$ & $6 \times 10^{2} \pm 1 \times 10^{2}$ & $6 \times 10^{2} \pm 1 \times 10^{2}$ & $6 \times 10^{2} \pm 1 \times 10^{2}$ \\
Coliforms (MPN) & $3 \times 10^{2} \pm 1 \times 10$ & $1 \times 10^{2} \pm 1 \times 10^{2}$ & $1 \times 10^{2} \pm 7 \times 10$ & $9 \pm 6$ & $3 \times 10^{2} \pm 1 \times 10^{2}$ \\
Faecal coliforms & $5 \times 10 \pm 2 \times 10$ & $7 \pm 5$ & $4 \pm 3$ & $<3 \pm 1$ & $3 \times 10 \pm 1 \times 10$ \\
(MPN) & & & & & \\
E. coli (MPN) & $3 \times 10 \pm 1 \times 10$ & $7 \pm 5$ & $4 \pm 3$ & $<3 \pm 0$ & $2 \times 10 \pm 1 \times 10$ \\
\hline
\end{tabular}

Table (3) Statistical analytical results of bacteriological examination of examined beef carcasses after preparation, the data is represented by mean \pm Standard Error (CFU or m.os $\left./ \mathrm{cm}^{2}\right)(n=20)$

\begin{tabular}{lccccc}
\hline \multicolumn{1}{c}{ Parameters } & Neck & Thorax & Shoulder & Abdomen & Thigh \\
\hline Mesophilic count & $5 \times 10^{6} \pm 2 \times 10^{6}$ & $5 \times 10^{6} \pm 2 \times 10^{6}$ & $7 \times 10^{6} \pm 4 \times 10^{6}$ & $5 \times 10^{5} \pm 2 \times 10^{5}$ & $2 \times 10^{5} \pm 3 \times 10^{4}$ \\
Psychrophilic count & $9 \times 10^{4} \pm 3 \times 10^{4}$ & $2 \times 10^{5} \pm 1 \times 10^{5}$ & $2 \times 10^{5} \pm 3 \times 10^{4}$ & $7 \times 10^{4} \pm 3 \times 10^{4}$ & $7 \times 10^{4} \pm 3 \times 10^{4}$ \\
Staphylococcal & $9 \times 10^{2} \pm 1 \times 10^{2}$ & $3 \times 10^{2} \pm 1 \times 10^{2}$ & $10 \times 10^{2} \pm 5 \times 10^{2}$ & $4 \times 10^{2} \pm 1 \times 10^{2}$ & $6 \times 10^{2} \pm 1 \times 10^{2}$ \\
count & & & & & \\
Coliforms (MPN) & $3 \times 10^{2} \pm 1 \times 10^{2}$ & $3 \times 10 \pm 1 \times 10$ & $8 \times 10 \pm 7 \times 10$ & $<3 \pm 0$ & $2 \times 10 \pm 1 \times 10$ \\
Faecal coliforms & $5 \times 10 \pm 2 \times 10$ & $<3 \pm 0$ & $<3 \pm 2$ & $<3 \pm 0$ & $7 \pm 5$ \\
(MPN) & & & & & \\
E. coli (MPN) & $2 \times 10 \pm 1 \times 10$ & $<3 \pm 0$ & $3 \pm 3$ & $<3 \pm 0$ & $<3 \pm 0$ \\
\hline
\end{tabular}

$1 \times 10,7 \pm 5$ m.os. $/ \mathrm{cm} 2$, respectively (Table 2 ), and after preparation they accounted for $<3 \pm 0,2 \times 10 \pm 1 \times 10,3 \pm 3,<3 \pm 0,<3 \pm 0$ m.os./cm2, respectively (Table 3 ).

\section{DISCUSSION}

Mesophilic counts: Fliss et al. (1991); Wanas (1995) and Ibrahim (1997) have obtained similar mesophilic count values to those of the present study. While lower figures were reported by Kandil (1992); Lasta et al. (1992); Khalafalla (1996); Paul and Murray (1997) and Murray et al. (2001). On the contrary, higher values were reported by Mulder and Krol (1976). Six and four out of 20 samples of shoulder and abdomen swabs after dehiding exceeded the permissible limits $\left(10^{6} \mathrm{CFU} / \mathrm{cm}^{2}\right)$ stated by ES (2004), respectively, while 4 and 5 samples exceeded such value after evisceration, however 7 and 5 samples 
exceeded the limit after preparation, respectively. In this respect, Mates (1983) stated that meat is unfit for human consumption when surface counts are more than $10^{6} / \mathrm{cm}^{2}$ and interior counts of $10^{5} / \mathrm{g}$. The high surface contamination of examined carcasses could be attributed to contaminated hides, which spread the bacteria during dressing. However, the skinning-associated factors such as equipment, tools and workers contributed such cross contamination during dressing (Bacon et al., 2000; and Collis et al., 2004). This is consistent with the hypothesis of Midgley and Desmarchelier (2001) who mentioned that tissues of healthy cattle are sterile before the first incision through the hide is made, but dressing procedures can lead to the transfer of bacteria from the hide onto the meat. Although, Mc Evoy et al. (2000) concluded that the slaughter of cattle with excessively dirty hides would result in increased bacterial contamination on the carcass, while Bell (1997) reported that it is much more difficult to restrict contamination from the hide. Other sources of contamination of carcass surface were recorded in the study of Nottingham (1982), which are the exterior and the gut of the animal, the knives, other utensils, butchery tables, etc., so that variations in count often reflect the hygienic conditions in the abattoir.

Psychrophilic counts: Lasta et al. (1992) reported nearly similar psychrophilic figures, while Abu-Eshi and Georgiev (1987) reported higher ones. The contamination with psychrophilic bacteria is originally of faecal origin; as well from soil and water. At the time of slaughter, the meat may be contaminated from the hands and clothes of the staff, from knives, and other equipment. Moreover, the cross contamination as carcasses are repeatedly handled during on- and off-loading at abattoir (Nortje et al., 1990).

Staphylococcal count: Nearly similar results of staphylococcal counts were reported by Desmarhelier et al. (1999). While lower figures were recorded by
Nortje et al. (1990) and Caprioli et al. (2000). On the other hand, Sokair and Anozie (1990), Mathieu et al. (1991) and Kandil (1992) recorded higher figures. The reasons of higher values of staphylococcal counts on the surface of examined carcasses are abattoir workers, as their hands were found to be highly contaminated; this is in accordance with the reports of Schlegelova et al. (2004). Additionally, Dickson and Anderson (1992) and Sokari and Anozie (1990) mentioned that contaminated skin, faeces, the contents of digestive organs, butchers' knives, hands, cloths and contaminated water are the main sources of contamination with Staphylococcal spp. during meat processing. In this respect, APHA (1992) stated that the presence of staphylococci is an indication of the preparation and handling of carcasses and meat by infected workers who are harboring the bacteria in their noses or skin or any infected lesions. Therefore, it is recommended that workers with sinus infections or recurrent cold and those with hand abrasions should be prevented from contribution in handling of slaughtered carcasses. Moreover, strict personnel hygienic measures should be adopted during preparation, dressing and handling of carcasses and meat.

Coliforms (MPN): Approximately similar values of coliforms (MPN) were obtained by Fliss et al. (1991), Emara (1992), Khalafalla (1996). However, higher figure was reported by Ibrahim (1997) and low figures were recorded by Kandil (1992) and Paul and Murray (1997). The surface contamination of beef carcasses with coliforms could be attributed to contamination from their intestine; however, hides and hooves contain large number of such organisms from soil, manure and feed. Besides, the contaminated water, utensils and equipment used in carcass slaughtering, dressing and evisceration, these results held the views previously reported of Guthrie (1988); Gracey and Collins (1992) and Marriot (1997). In general, the coliforms are 
undesirable organisms in foods, and their presence on surface of carcasses is considered an indication of sewage contamination and hence of the possible presence of enteric pathogens (Frazier and Westhoff, 1989).

Fecal coliforms: In this regard, Wanas (1995) and Vanderlinde et al. (1998) obtained approximately similar results, while higher figure was reported by Ibrahim (1997). According to the maximum acceptable limit of faecal colifroms stated by ICMSF (1980), it was clear that none of the examined carcasses is not acceptable according to such limit. In this concern, it was reported by Nortje and Naudè (1981) that after completion of a typical hygienic dressing to beef carcass, it is likely to carry from 10 to 100 faecal coliforms $/ \mathrm{cm}^{2}$. It is well known that the presence of fecal coliforms on the surface of slaughtered beef is related to faecal contamination. This substantiates the hypothesis reported by Banwart (1981) that faecal coliforms can originate from improperly sanitized working surfaces during dressing of carcasses, therefore, their presence would reflect the quality of sanitation. In this respect, Frazier and Westhoff (1989) pointed out that during slaughter, dressing and evisceration, microorganisms came chiefly from the contaminated hide, water, floor and the intestinal tract.

E. coli (MPN): The analysis of foods of animal origin for the levels of $E$. coli has been widely recognized as a pointer for fecal contamination. Nevertheless, the presence of such organism indicates the possibility of occurrence of microbiological hazards. Accordingly, these findings confirm the fecal contamination of examined beef carcasses during different stages of preparation and alarm the presence of public health risk; this is in accordance with that reported by Brown and BairdParker (1982).

\section{CONCLUSION}

From the current study, it could be concluded that six and four out of 20 samples of shoulder and abdomen swabs after dehiding exceeded the permissible limits of total bacterial count $\left(10^{6}\right.$ $\mathrm{CFU} / \mathrm{cm}^{2}$ ) stated by ES (2004), while four and five samples exceeded such value after evisceration, however seven and five samples exceeded the limit after preparation, respectively. The bacterial contamination of carcass surfaces originates mainly from the exterior and the GIT of the animal, but also from knives, utensils, water, and handlers. The presence of staphylococci is a sign of contamination by infected workers. The surface contamination of beef carcasses with coliforms could be attributed to contamination from GIT; however, hides and hooves harbor large number of such organisms and contribute in contamination. Finally, the surface contamination of slaughtered animals with fecal coliforms and/or E. coli is of no doubt that fecal contamination occurred. The level of contamination by microorganisms was found to increase gradually with the different stages of carcass preparation because additional sources were involved.

\section{REFERENCES}

Abu-Eshi, I. and Georgiev, L. 1987. Effect of slaughterhouse capacity on the hygienic production of beef. Vet. Med. Nauki, 24:3-7.

Anderson, M.E., Marshall, R.T. and Dickson, J.S. 1992. Estimating depths of bacterial penetration into post-rigor carcass tissue during washing. J. Food Safety, 12: 191-198.

AOAC (Association of Official Analytic Chemists) 1990. Official Methods of analysis. $15^{\text {th }}$ Ed., Association Official Analytic Chemist, Arlington VA, USA.

APHA 1992. Standard methods for the examination of water and waste water. $18^{\text {th }}$ ed. American Public Health Association, Washington, DC. 
Bacon, R.T., Belk, K.E., Sofos, J.N., Clayton, R.P., Reagan, J.O. and Smith, G.C. 2000. Microbial populations on animal hides and beef carcasses at different stages of slaughter in plants employing multiple-sequential interventions for decontamination. J. Food Prot.; 6: 1080-1086.

Banwart, G.J. 1981. Basic food microbiology USAS by say brook press. Inc., 480.

Bell, R.G. 1997. Distribution and sources of microbial contamination on beef carcasses. J. Appl. Microbiol., 82: 292.

Brown, M.H. and Baird-Parker, A.C. 1982. The microbiological examination of meat. In: Brown, MH (Ed), Meat Microbiology. Applied Science Publishers, London, pp. 423-520.

Caprioli A., Busani L., Martel J.L. and Helmuth, 2000. Monitoring of antibiotic resistance in bacteria of animal origin. Epidemiological and microbiological methodologies. Int. J. Antimicrob. Agents, 14: 259-301.

Collis, V.J.; Reid, C.A.; Hutchison, M.L.; Davies, M., H.; Wheeler, K.P.A.; Small, A. and Buncic, S. 2004. Spread of marker bacteria from the hides of cattle in a simulated livestock market and at an abattoir. J. Food Prot., 67:2397-24032.

Dickson, J.S. and Anderson, M.E. 1992. Microbiological decontamination of food animal carcasses by washing and sanitizing systems: A review. J. Food Prot., 55:133- 140.

ES (Egyptian Standards) 2004. Egyptian standards for requirement of fresh meat, No. 4334. Egyptian Organization for Standardization.

Emara, M. 1992. Meat quality of slaughtered cattle and buffalo. M. V. Sc., Thesis (Meat Hygiene) Fac. Vet. Med., Cairo University.

Eugène $\mathrm{N}$, Divine $\mathrm{B}$. and Martin, $\mathrm{P}$. O. 2013. Assessment of beef meat microbial contamination during skinning, dressing, transportation and marketing at a commercial abattoir in Kigali city, Rwanda. Pakistan Journal of Food Sciences, 23: 133-138.

Fliss, S., Simard, R.E. and Ettriki, A. 1991. Microbiological quality of different fresh meat species in Tunisian slaughterhouses and markets. J. Food Prot., 54: 773.

Frazier, W.C. and Westhoff, D.C. 1989. Food Microbiology, $4^{\text {th }}$ Ed. Mc-Graw Hill Book Comp. New York.

Gracey, J.F. and Collins D.S. 1992. Meat Hygiene, $9^{\text {th }}$ Edition. Bailliere Tindall, London.

Guthrie, R. K. 1988. Food Sanitation. $3^{\text {rd }}$ Ed. An AVI Book, Van Nostrand Reinhold, New York.

Ibrahim, L. M. 1997. Sanitary status of meat in Assuit Governorates villages. M. V. Sc., Thesis (Meat Hygiene) Fac. Vet. Med., Assuit University.

ICMSF (International Commission on Microbiological Specifications for Foods) 1980. Microbial Ecology of Foods: Food commodities, 2nd Ed., Academic Press, New York.

Kandil, K.M., 1992. Bacteriological survey of contamination of carcasses immediately after slaughter. M.V.Sc., Thesis (Meat Hygiene) Fac. Vet. Med., Alex. University, Egypt.

Khalafalla, F.A. 1996. Microbial evaluation of raw meat, meat products and nonmeat ingredients. Beni-Suef Vet. Med. Res., 4:141.

Lasta, J. A., Rodriguez, R., Zanelli, M. and Morgaria, C. A. 1992. Bacterial count from bovine carcasses as an indicator of hygiene at slaughtering places. A proposal for sampling.

Marriot, N.G 1997. Essentials of Food Sanitation. Chapman \& Hall. Food Science Texts. New York.

Mates, A. 1983. Microbiological Survey of Frozen Ground Meat and A Proposed Standard. J. Food Prot., 46:87.

Mathieu, A.M., Isigidi, B.K., Oevriese, L.A., Godard, C. and Mccracken, R.M. 1991. Salmonella isolates from 
humans and production animal species in Northern Ireland from 1979-1988. Society from Vet. Epidemiology and Preventive Medicine, 24-48.

Mc Evoy, A.M., Finnerty, M., Sheridan, J.J., McGuirel, Blair L.S., McDowe, D.A. and Harrington, D. 2000. The relationship between hide cleanliness and bacterial numbers on beef carcasses at a commercial abattoir. Lett. Applied Microbiology, 30: 390 395.

Midgley, J. and Desmarchelier, P. 2001. Pre-slaughter handling of cattle and Shiga toxin-producing Escherichia coli (STEC). Letters in Appl. Microbiol., 32: 307-311.

Mulder, S. J. and krol, B. 1976. A study on the bacteriological aspect of fresh beef. I Effect of storage of slaughter cattle. A. transe Tijdschrift voor diergeneeskunde, 101:594 - 598.

Murray, K.A.; Gilmour, A. and Madden, R.H. 2001. Microbiological Quality of Chilled Beef Carcass in northern Ireland: a baseline survey. J. Food Prot., 64: 498- 502.

Nortje, G. L. and Naudè, R.T. 1981. Mcrobiology of beef carcass surfaces. J. Food Prot., 44, 355.

Nortje, G.L., Nel, L., Jordaan, E., Badenhorst, K., Goedhart, G.; Holzapfel, W.H. and Grimbeek, R.J. 1990. The influence of incubation temperature on bacterial counts in a meat production system. J. Food Prot., 53:418-422.

Nottingham, P. M. 1982. Microbiology of carcass meats. In Meat Microbiology, edited by M. H. Brown. Applied Science Publishers Ltd. London \& New York.

Paul, B. V. and Murray J. 1997. Microbiological quality of Australian beef carcasses meat and frozen bulk packed beef. J. Food Saf., 16:363.

Schlegelova J.; Napravnikova E.; Dendis M.; Horvath R.; Benedik J.; Babak V.; Klimova E.; Navratilova P.; Sustackova A. 2004. Beef carcass contamination in a slaughterhouse and prevalence of resistance to antimicrobial drugs in isolates of selected microbial species. Meat Science, 66: 557-565.

Sokari, T.G. and Anozie, S.O. 1990. Occurrence of enterotoxin producing strains of Staphylococcus aureus in meat and related samples from traditional markets in Nigeria. J. Food Prot., 53:1069.

Vanderlinde, P.B.; Shay, B. and Murray, J. 1998. Microbiological quality of Australian beef carcasses meat and frozen bulk packed beef. J. Food Prot., 61: 437.

Wanas, M.A. 1995. Surface contamination of carcasses in modern and traditional abattoirs. M.V.Sc., Thesis (Meat Hygiene) Fac. of Vet. Med., Alex. University, Egypt. 